\section{The economic situation and challenges to management}

\author{
Chris J. van Wyk \\ Joint Managing Director, The Trust Bank of Africa Ltd., P.O. Box 7694 \\ Johannesburg 2000, Republic of South Africa
}

Address to Fedmech Dealer's Annual General Meeting at Sun City, April 21, 1982.

\section{Huidige ekonomiese klimaat}

Tot sommer onlangs nog het Suid-Afrikaanse sakemanne 'n gunstige ekonomiese klimaat en voorspoed in oorvloed beleef. Hoë omsette, buitengewone winste en goedkoop, volop finansiering was aan die orde van die dag. Hierdie situasie het egter vinniger verander as wat baie mense verwag het met die gevolg dat talle van ons nou met probleme sit wat dringende aandag nodig het en baie finansiële ongerief veroorsaak.

Die belangrikste kenmerke van die huidige ekonomiese situasie is dat omsette besig is om af te plat en selfs te daal; krediet word al skaarser; finansieringskoste is baie hoog; voorrade hoop op; debiteurstermyne verleng; die risiko van slegte skuld neem toe; verkooppryse kom onder druk en winste word al moeiliker gehandhaaf.

Die feit dat banke se prima uitleenkoerse sedert die begin van verlede jaar meer as verdubbel het tot die huidige $20 \%$ en dat finansiële instellings vir klein uitleentransaksies tot $24 \%$ rente vra, beklemtoon die toestand van finansiële knapheid.

Vanjaar gaan dus deur swakker saketoestande as 1980 en 1981 gekenmerk word. Sakemanne sal veel vindingryker moet wees en strenger bestuursbeginsels toepas om kop bo water te hou. Die landbou-meganiese bedryf sal enersyds dié afkoeling voel as gevolg van swakker landbou-oeste en die laer vlakke van trekker-aankope as gevolg van die Atlantis Dieselenjin-situasie wat nou verby is.

'n Ander rede is egter dat die oorverhitting van die ekonomie wat teen die einde van 1980 reeds duidelik sigbaar was, daartoe gelei het dat die owerheid die remme 'n geruime tyd al aandraai. 'n Matige ekonomiese afkoeling het verlede jaar reeds ingetree. Buitelandse ekonomiese stagnasie en rekordhoë internasionale rentekoerse het ons binnelandse ekonomiese afkoeling verder aangehelp. Die einde van hierdie fase is ongelukkig nog nie bereik nie. So 'n verposing is egter nodig vir die nasien en opknapping van die oorverhitte ekonomiese masjien, wat ook op hierdie stadium ietwat oorwerk is.

Die afkoelingsfase gaan meebring dat 'n hele aantal ondernemings ten gronde sal gaan. So toon wèreldwye ondervinding dat veral die middelslag en kleiner ondernemings 'n hoë ongevallesyfer wys wanneer die ekonomie verswak, omsette en winste daal, kompetisie moeiliker raak en geld skaars en duur word. Wetende dat dit die onverbiddelike verloop van die ekonomiese siklus is, moet ons nou dubbel so hard daaraan werk om kop bo water te hou. Dit is nie nou die tyd om wanhopig te raak nie, want dit is hoofsaaklik die droë en vrot hout wat uitgesny word om plek te maak vir die nuwe, welige lote van die volgende ekonomiese groeiseisoen.

\section{A bank's approach to this situation}

You may well ask how banks approach their business in a deteriorating phase of the business cycle.

Part of the answer is to realize that a bank is a business just like any other business; when times are hard, banks feel the pressure just like anyone else. In difficult times it is therefore unsound policy for a bank to be as lenient in respect of granting additional credit or extending repayment as when business is booming.

These days banks will thus tend to become more cautious and conservative. They will tend to increase lending rates, be stricter in assessing credit applications and be more watchful in regard to outstanding debt as more difficult business conditions emerge.

For you as dealers in the tractor and farm machinery trade, it is therefore likely to become more difficult to arrange and obtain sufficient finance for a rising stockpile and growing debtor book. In addition, your clients might find it more difficult to raise finance for their purchases from you. Having regard to all this, you may well wonder how you should approach the very important matter of ensuring that adequate finance will be available for the running of your business.

In this regard it might be instructive to consider the principal guidelines followed by banks in evaluating credit applications. These guidelines always apply. They do not change when the economy changes. But they are enforced more strictly in the more difficult times when business conditions deteriorate amidst more stringent financial conditions, that is as finance becomes scarcer and dearer.

Firstly, banks evaluate the financial history of the applicant business enterprise. This is done by anaiysing financial statements for the past few years. From this analysis a picture is obtained of the liquidity, solvability and profitability of a business, or in general terms, the past trend of its ability to meet its short-term commitments. By and large this exercise focuses on a comparison of current assets and current liabilities since corporate liquidity has proved to be the most effective financial anchor in times of economic instability. Having done this kind of analysis, the position of the business in relation to pressures from the environment will be reasonably clear.

The solvability of the business also requires scrutiny as it relates to the extent to which the business is funded with outside debt. This is important to the financier in judging the long-term risk.

We know that profitability is the success indicator of the business. A comparison of profit with interest paid guides us towards the extent to which additional finance can safely be borrowed and serviced.

Equally important is the fact that banks assess the management of the business to satisfy themselves that the 'people competence' and leadership exist to carry the concern through difficult times. Appropriate business experience and a proven track record are two of the most important qualifications required by a financial institution when assessing a borrower.

Naturally and very importantly, banks also evaluate the expected future of the business. Information regarding this expected future financial requirements and its expected ability to meet its future commitments, is derived from a projected cash flow statement. The cash flow statement 
also tells us a lot about the financial management capabilities of the people in charge of the business.

\section{Uitdagings aan bestuur}

U sal seker met my saamstem dat al hierdie sake besondere eise op die bestuur van 'n onderneming plaas. Indien die bestuurder die probleme van vandag egter as uitdagings beskou, sal dit meebring dat die onderneming baie sterker sal wees wanneer die ekonomie die volgende groeifase betree. Dit is egter nodig dat die bestuurder homself die regte vrae vra om die geleenthede wat uit die probleme voortspruit, te benut.

Dit is maklik wanneer ' $n$ onderneming ten gronde gaan om te sê dat sy bank hom nie verder wou finansier nie, dat lone, salarisse en ander koste handuit geruk het, of dat die regering 'n onsimpatieke maatreël ingestel of houding ingeneem het. Nadere ondersoek dui egter gewoonllk daarop dat feitlik dieselfde swakplek deurgaans tot sakemislukkings aanleiding gee, naamlik 'n tekort aan bestuurskennis en dus verwaarlosing van die toepassing van bestuursbeginsels.

Wat bestuur betref, sal veral die kleinsakeman meer professioneel moet begin dink indien hy sy voortbestaan wil verseker. Besigheid is vandag so mededingend dat ' $n$ professionele benadering in alle ondernemings onontbeerlik geword het.

Dit is nie altyd maklik vir veral ons klein sakemanne om hierdie standpunt te onderskryf nie. Maar ek wil dit beklemtoon dat die sakeman sal moet aanpas by die eise van ons tyd, of moet vergeet van die toekoms.

Ek wil graag saam met $u$ kyk na 'n paar terreine waar aanpassings by veranderde omstandighede vir die sakeonderneming noodsaaklik geword het.

\section{Toepassing van bestuursbeginsels}

'n Onderneming ontwikkel, net soos die mens, vanaf babastadium tot volwassestadium. Die bestuursbenadering wat gedurende die verskillende stadiums gevolg word, moet noodgedwonge verander.

Bestuursbenadering en bestuursvaardigheid is egter onafskeidbaar. Gevolglik vereis 'n veranderde bestuursbenadering ook 'n ander bestuursvaardigheid. Die eienaarbestuurder van 'n onderneming moet dus besef dat hyself op so 'n wyse van werker na bestuurder na uitvoerende beampte moet vorder dat die groei van die onderneming en die groei van die personeel nie vertraag word nie.

'n Moderne en meer wetenskaplike benadering tot ondernemingsbestuur word blykbaar die meeste belemmer deurdat uitvoerende amptenare die beplanning- en beheerfunksie verwaarloos.

Dit gebeur te dikwels dat daar geen beplanning gedoen word nie, of dat daar op 'n lukraak wyse beplan word. Beplanning is nie net 'n proses van vooruitdink nie; dit behels ook die stel van mikpunte en die ontwikkeling van spesifieke planne om die mikpunte te bereik.

Die vinnig veranderende wêreld waarin ons leef, vereis dat baie aandag aan die toekoms gegee moet word. Goedgeformuleerde planne stel inderwaarheid die bestuurder in staat om geleenthede vroegtydig te identifiseer en gevolglik beter te benut.

Maar goedgeformuleerde planne help weinig indien die planne nie beheerpunte verskaf nie. Daar moet periodiek nagegaan kan word of alles nog volgens plan verloop. Indien daar eers aan die einde van 'n lang periode - sẻ die volle finansiële jaar - ontdek word dat die onderneming se mikpunte nie bereik is nie, is dit te laat om iets daaraan te doen. Gevolglik is dit nodig dat daar betyds en deurlopend van afwykings kennis geneem moet word sodat regstellende stappe gedoen kan word om te verseker dat mikpunte wel bereik sal word.

Indien u as sakeman die eise van die tyd wil oorleef, is dit nodig dat $u$ die basiese beginsels van bestuur moet ken, dat $u$ die take uitvoer wat van 'n bestuurder verwag word en nie so vasgevang word in die dag-tot-dag take van 'n onderneming dat daar geen tyd vir die bestuurstake be staan nie.

As 'n mens jou aandag op bestuurstake toespits, hou dit ' $n$ verdere voordeel in, naamlik dit dwing jou om selfdissipline aan die dag te lê om jou beskikbare tyd ten beste te benut. Doeltreffende bestuurders rangskik hulle take in volgorde van belangrikheid en handel hulle ook in daardie volgorde af. Verder word toepaslike take aan ondergeskiktes gedelegeer wat die bestuurder meer tyd gee om aan sy bestuursfunksies te bestee.

\section{Opbou van 'n geskikte personeelkorps}

Ons in Suid-Afrika bevind ons met 'n onbenydenswaardige oorvloed ongeskoolde arbeid, terwyl daar terselfdertyd 'n tekort aan geskoolde arbeid bestaan.

Die tyd het lank reeds aangebreek dat baie meer aandag aan die opleiding van werkers bestee moet word. Of sien ons op teen die onmiddellike koste van die opleiding van 'n onproduktiewe werker terwyl die uiteindelike koste van onhandige, onervare en onopgeleide werkers so duidelik opwys in swak gehalte werk, 'n hoë kostestruktuur, vervreemding van klante en uiteindelike agteruitgang van die besigheid? Versuim om ons werkers behoorlik toe te rus vir die dagtaak lei ook tot ' $n$ hoë personeelomset of personeel wat met verdeelde aandag werk omdat hulle so dikwels na ander geleenthede soek.

\section{More sophisticated financial management}

An enquiry among business managers about the most pressing limiting factors to business expansion would probably accord a high ranking to 'inadequate financial resources'. However, research has indicated that in many businesses this constraint is more perceived than real, and that it often results from the incorrect application of financial resources. It is often found that a business carries more stock than is necessary and that too much funds are locked into fixed assets. These items cannot always easily be converted into cash. Thus overstocking and heavy investment in fixed property can easily result in a shortage of funds which can handicap the company via an inability to utilize cash discounts, and by weakening its general competitive position through illiquidity.

Financial planning has become a very important function in any business. The benefits stretch beyond improving profitability: sound financial management also fetches high marks with financial institutions should an application for financial assistance be made.

Your banker can be of much assistance in your financial planning. He is the man with the appropriate financial expertise and insight who should stand closest to you 
with advice on financial planning.

Perhaps this is the appropriate time to say something about the relationship between a business and its bank. Bankers frequently get the impression that clients believe that information should only be provided to their bank when application is made for finance. It might be much more rewarding to regard your bank as a partner in your business, especially when bank loans are employed in your company. Like any other partner, your bank should know what happens in the business and what is being planned. The relationship between bank and client is one of mutual trust and to be informed, strengthens the position of trust. I am sure that if mutual trust exists between you and your bank manager, and if you continue to discuss the strengths and weaknesses of your business with him, then he will go out of his way to help you when assistance is needed. Such a relationship will more often than not assure survival while an unwise competitor might go bust because of his banker removing the umbrella just as the bad weather closes in.

Your partnership with your bank manager represents one of the most valuable team actions for the continued future success of your business.

\section{Die bestuur van bates in ondernemings}

Tot op hierdie stadium het ek my besig gehou met 'n algemene bespreking van die huidige ekonomiese toestande en wat $\mathrm{u}$ moet doen om die uitdagings te trotseer. Ek wil nou graag ' $n$ bietjie stilstaan by 'n saak wat ons almal na aan die hart lê, naamlik die bestuur van bates in 'n onderneming. Eerstens kyk ons na die wyse waarop bates gefinansier behoort te word, vervolgens na wat die invloed van kortings op u onderneming kan wees, en laastens hoe doeltreffende bestuur van bedryfskapitaal $u$ winste kan verhoog.

\section{Die finansiering van vaste bates}

Die belangrikste beginsel betrokke by die finansiering van vaste bates is om te alle tye te verhoed dat fondse wat vir korttermyndoeleindes benodig word, vir die aankoop van vaste bates gebruik word. Vaste bates word gekoop met die oog daarop om dit oor 'n lang tydperk te gebruik. Daarom behoort vaste bates met langtermynfondse gefinansier te word soos, byvoorbeeld, termynlenings of teruggeploegde winste. Indien vaste bates met lenings gefinansier word, behoort die terugbetalingstermyn by die ekonomiese lewensduur van die bate aan te pas.

Langtermynverpligtinge plaas uit die aard van die saak nie oormatige druk op die kontantposisie van die onderneming nie. Nogtans moet langtermynlenings met sorg aangegaan word, veral ten tye van stygende rentekoerse en afplattende of dalende omsette aangesien so ' $n$ verloop van sake beteken dat 'n groter wordende rentelas uit ' $n$ krimpende inkomste betaal sal moet word. Die behoefte aan langtermynfinansiering moet dus met sorg bepaal word met die onderneming se verwagte vermoë om die rentelas te kan absorbeer as een van die belangrike oorwegings.

\section{Die finansiering van bedryfsbates}

In teenstelling met die finansiering van vaste bates, kan bedryfsbates uit sowel langtermyn- as korttermynfondse gefinansier word. Die verhouding waarin die twee soorte finansiering gebruik word, wissel van onderneming tot onderneming. As 'n algemene riglyn behoort egter nie meer as die helfte van u bedryfsbates deur korttermynlenings gefinansier te word nie.

\section{Die invloed van kortings op winsgewendheid}

In hierdie dae van hoë rentekoerse en inflasie, moet alles moontlik gedoen word om koste te bespaar. Onder sulke toestande ontstaan kontantvloeiprobleme gewoonlik en is die aangewese aksie om kontant so vinnig moontlik te realiseer en betalings so stadig moontlik te doen. Dit is 'n beleid waarmee geen fout gevind kan word nie, op voorwaarde dat kortings nie onoordeelkundig verbeur of toegestaan word nie. Indien kortings ter sprake is, vereis dit eers ' $n$ paar berekeninge om die winsgewendste optrede te bepaal.

As voorbeeld wil ek die volgende geval aan u stel, soos in Tabel 1 aangedui word: gestel een van u krediteure laat u 'n kontantkorting van $5 \%$ toe indien daar onmiddellik vir die goedere betaal word. Betaal u nie onmiddellik nie, word die korting verbeur en moet die volle bedrag binne 30 dae betaal word. Wat sal u besluit wees?

$\mathrm{U}$ sien in Tabel 1 dat vir die gebruik van die fondse vir 'n verdere 30 dae teen $5 \%$ rente dit op 'n enkelvoudige rentebasis reeds $60 \%$ per jaar kos as u sou besluit om die korting prys te gee. Dit lyk nie na 'n goeie ruil nie. Indien $\mathrm{u}$ dieselfde korting aan $\mathrm{u}$ kliënte gee, is dit natuurlik ook waar dat u $60 \%$ per jaar vir die gebruik van die fondse betaal deur dit onmiddellik teen ' $n$ 5\% korting in te vorder. Voordat enige besluit dus oor kortings geneem word, is dit belangrik dat sorgvuldige berekeninge vooraf gedoen word.

\section{Tabel 1 Effek van kontantkorting van $5 \%$}

\begin{tabular}{|c|c|}
\hline Korting vir kontant & $=5 \%$ \\
\hline Kredietperiode & $=30 \mathrm{dae}$ \\
\hline $\begin{array}{l}\text { Koste om fondse vir 'n addisionele } \\
\text { periode te gebruik }\end{array}$ & $=5 \%$ \\
\hline Getal periodes per jaar $\frac{360}{30}$ & $=12$ \\
\hline Koste van fondse oor 'n periode van & \\
\hline 1 jaar & $\begin{aligned}= & 5 \% \times 12 \\
= & 60 \% \text { op 'n enkelvoudige } \\
& \text { rentebasis }\end{aligned}$ \\
\hline
\end{tabular}

Gevolgtrekking: Dit is klaarblyklik te duur om onder dié omstandighede die korting te verbeur

\section{Management of working capital}

A discussion of working capital management mostly covers three controllable items, namely creditors, stock and debtors. The interrelationship between these items has a deciding impact on the amount of cash needed by the business to run its operation.

Let us consider the example of a business with a cost of sales of R900 000 during any specific year. In this business, debtor collections take place after 90 days, stock is carried for 120 days and creditors are paid after 30 days. The situation will then be as indicated in Case 1 (see Table 2). 
Table 2 Working capital management, Case 1

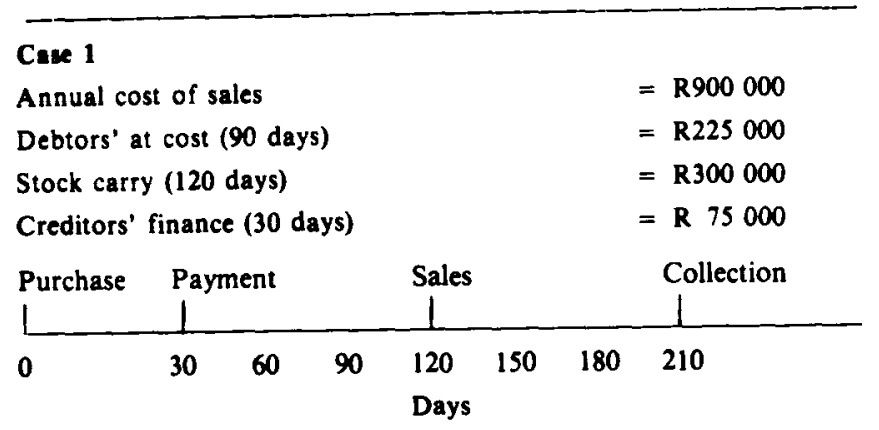

Amount of finance required:

$\begin{array}{ll}\text { Stockkeeping } & \text { R300000 } \\ \text { Plus debtors } & \text { R225000 } \\ & \text { R525000 } \\ \text { Less creditors } & \text { R } 75000 \\ \text { Total amount } & \text { R450000 }\end{array}$

At prime overdraft lending rate of $20 \%$ total finance charges amount to R90 000 per year

Hence, to finance debtors and stock, R450 000 working capital is required at an annual interest cost of R90000 if the prime overdraft lending rate is $20 \%$.

What would happen if the management of this business could shorten the stockholding period by 30 days as shown in Case 2? (See Table 3.)

In Case 2 the business will need R375 000 in working capital to finance debtors and stock. This represents a reduction in finance required of $R 75000$ compared with Case 1, and an interest saving of R15000 per year if the cost of funds remains at $20 \%$.

A similar effect would be achieved if the creditors' period can be lengthened or the debtors' period shortened by the same period.

Next, let us consider Case 3 where the debtors' period is shortened to 60 days, the creditors' period lengthened to 60 days and stock has to be carried for 90 days, as shown

Table 3 Working capital management: shorter stockholding period

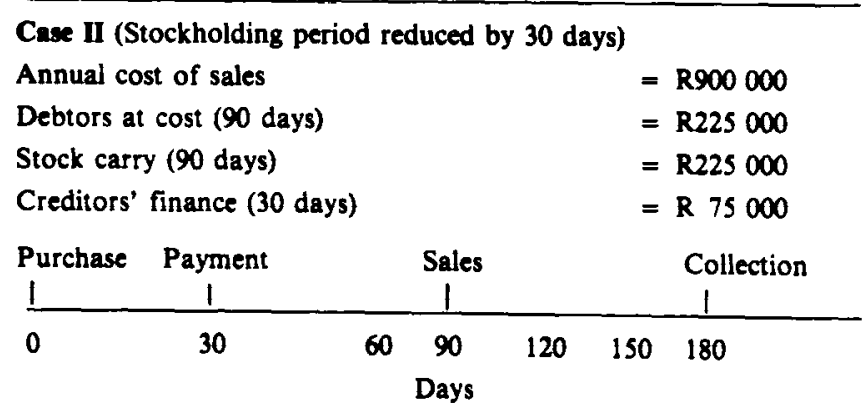

Amount of finance required:

$\begin{array}{ll}\text { Stockkeeping } & \text { R225000 } \\ \text { Plus debtors } & \text { R225 000 } \\ & \text { R450000 } \\ \text { Less creditors } & \text { R } 75000 \\ \text { Total amount } & \text { R } 375000\end{array}$

At prime overdraft lending rate of $20 \%$ annual finance charges amount to R75 000. Hence a saving of R15000 p.a. over Case I. in Table 4.

If this situation can be achieved, only R225 000 will be required to finance stock and debtors. Hence only $50 \%$ of the finance requirement of Case 1 at only $50 \%$ of the original finance charges.

Table 4 Working capital management: shorten debtors' period, extend creditors' period

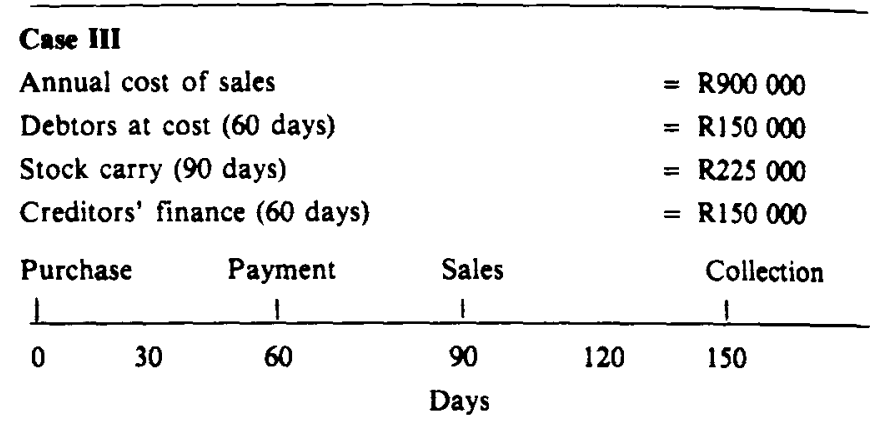

Amount of finance required:

Stockkeeping

R225 000

Plus debtors

Ri50 000

R $\overline{375000}$

Less creditors

R150000

Total amount

$\mathbf{R 2 2 5 0 0 0}$

At prime overdraft lending rate of $20 \%$ annual finance charges amount to R45 000. Hence a saving of R45000 p.a. over Case I.

\section{Impact of Inflation on working capital requirements}

Let us superimpose a $15 \%$ inflation rate on Case 1 and consider its impact on working capital requirements, as indicated in Table 5 on page 155 .

The result is an increase of $R 67500$ in working capital required which adds R13 500 to the interest burden (at prime bank overdraft rate of $20 \%$ ). To retain the annual interest cost at the R90 000 of Case 1, we now require a reduction of 23,5 days in the cash flow cycle, that is a reduction from 180 to 156,5 days. This can be achieved by reducing the stock carrying or debtors' outstanding period by 31,5 days, increasing creditors' terms by this number of days, or effecting a combination of these giving the same result.

\section{Ten slotte: enkele praktiese wenke}

- Kyk indringend na die bestuur van u bedryfskapitaal; hou die verloop van voorrade, debiteure en krediteure fyn dop en stel aksieplanne in werking om termyne só te $\mathrm{krimp} / \mathrm{rek}$ dat u die maksimum-voordeel verkry.

- Moenie korting verbeur of toestaan voordat u sorgvuldige berekeninge oor die koste daarvan gedoen het nie.

- Kies die finansieringstermyn om aan te pas by die ekonomiese lewe van die bates wat gefinansier word.

- Bepaal u kontantbehoeftes vooraf deur kontantbegrotings op te stel.

- Hou u bankbestuurder ingelig en bou 'n goeie verstandhouding met hom op sodat $u$ ' $n$ finansiële sambreel kan hê wanneer die ekonomiese reën weer begin uitsak. 
Table 5 Impact of inflation on working capital requirements

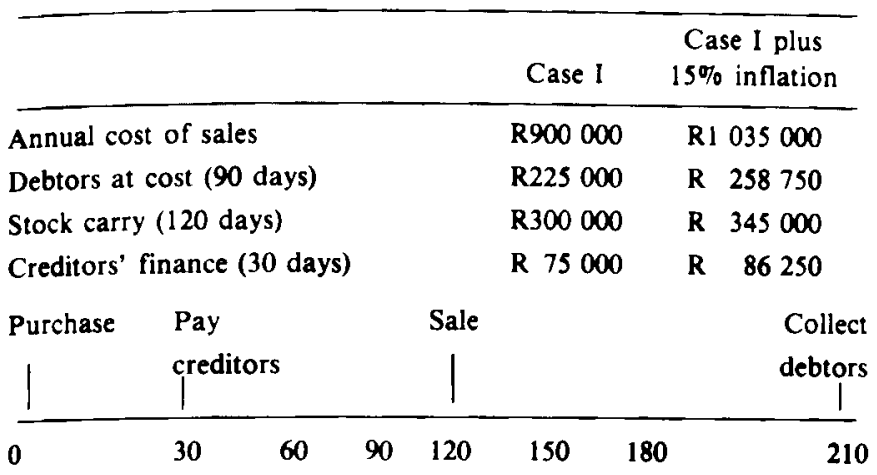

The working capital requirement changes as follows:

\begin{tabular}{lll}
\hline & Case I & $\begin{array}{c}\text { Case I plus } \\
15 \% \text { inflation }\end{array}$ \\
\hline Stock carry & $\mathbf{R 3 0 0 0 0 0}$ & R345 000 \\
Plus debtors & R225000 & R258750 \\
\cline { 2 - 3 } & R525000 & R603750 \\
Less creditors & R 75000 & R 86250 \\
\cline { 2 - 3 } & R450 000 & R517500
\end{tabular}

Annual finance charges at prime

bank overdraft rate of $20 \%$

R $90000 \quad$ R 103500

Increased interest charges as a result

of inflation

R 13500

Hence, 23,5 days reduction in cash flow cycle required to recoup R 13500 additional finance charges.

Om mee af te sluit: $\mathrm{U}$ moet sorg dat elke sent wat u beskikbare finansiering kan verdien 'n bydrae tot $u$ wins lewer, want finansiering is skaars en duur. Finansiering weier nie om oortyd te werk nie, dit neem ook nie verlof nie, dit word nie deur vakbonde beheer nie en slaap nie in die nag nie. Daarom moet u dit 24 uur per dag hard laat werk.

\section{HSRC Investigation into Intergroup Relations: The programme and its financing}

\author{
H.C. Marais and Lynette Dreyer \\ Human Sciences Research Council (HSRC), Private Bag X270, \\ Pretoria 0001, Republic of South Africa
}

\section{Introduction}

Economists in particular and social scientists in general are invited to participate in the HSRC Investigation into Intergroup Relations. A budget independent of the usual financing of research at universities is available for research into the most pressing aspects of the relationships between the major groups in South Africa.

This article provides information on the background to and management of the HSRC Investigation into Intergroup Relations. At the same time it is also an invitation to the research community to participate in the programme by applying for financial assistance.

\section{Background}

Research councils in most industrialized countries initiate and support problem-oriented research. In this way research can contribute towards a better understanding of the nature and process of pressing social problems. The Human Sciences Research Council since 1980 also administers a budget specifically provided for problemoriented research.

By their very nature social problems are multidimensional. The accent is therefore placed on the co-operation of as many researchers as possible from different research organizations, as it is obvious that a single organization in South Africa cannot approach a comprehensive problem multidisciplinarily, on its own. The co-operative approach also implies that such a problem can be approached from different ideological, theoretical and methodological perspectives simultaneously.

The first research programmes that were undertaken within this framework were the HSRC Investigation into Sport under the leadership of Prof. G.J.L. Scholtz of the Potchefstroom University for CHE, and the HSRC Investigation into Education under the leadership of Prof. J.P. de Lange of the Rand Afrikaans University.

From a survey that was conducted during 1980 , the field of intergroup relations emerged as the single most important area for research in South Africa (see HSRC Research Bulletin, 1981, 11(2), 1-3). Consequently the Research Priorities Committee representing the major research sectors in South Africa, recommended to the HSRC that a broad investigation into intergroup relations be undertaken. This recommendation was accepted and during 1981 planning started. The investigation was thus solely initiated by the HSRC.

\section{Research management and organization}

The HSRC Investigation into Intergroup Relations is managed and controlled by a main committee. The main committee consists of experts representing the sectors that have a direct interest in intergroup relations.

\section{Fields and work committees}

Because the research area, intergroup relations, is potentially so vast, following guidelines are necessary for the delineation of the investigation:

- The accent falls on the relations between the main population groups in South Africa like the Afrikaansand English-speaking Whites, urban and homeland Blacks, Coloureds, Indians and large immigrant groups.

- The basis on which the population is analysed (for example in terms of interest groups), will be partly determined by the theoretical stand of the researcher.

- The research is problem-oriented and thus focuses on the most topical aspects of intergroup relations.

The main committee divided the area into thirteen fields: Theory and methodology Historical aspect 